\title{
WIESLAW RYMAJDO
}

ORCID: 0000-0003-3004-1121

\section{POLACY WE WSPÓLCZESNEJ REPUBLICE LOTEWSKIEJ. SPOŁECZNO-KULTURALNA AKTYWNOŚĆ MNIEJSZOŚCI POLSKIEJ}

DOI: $10.15290 /$ sp.2018.26.09

\begin{abstract}
Abstrakt. Niniejszy artykuł przedstawia sytuację demograficzną, polityczną i społeczną Polaków we współczesnej Republice Łotewskiej. Na podstawie badania wyników łotewskiego spisu powszechnego z 2011 r. omówiona została perspektywa demograficzna mniejszości polskiej. Po $1991 \mathrm{r}$. w wyniku przychylności władz łotewskich społeczność polska odzyskała możliwość działalności organizacyjnej. Opracowanie pokazuje proces odbudowy struktur organizacyjnych polskiej społeczności. Ukazany został również proces tworzenia od podstaw szkolnictwa polskiego, a także obecne wyzwania szkół polskich związane zarówno z ich wewnętrznymi problemami, jak i z długofalową polityką władz łotewskich. Praca przedstawia również największe problemy Polaków na Łotwie, oraz rysuje możliwe perspektywy ich rozwiązania przy pomocy władz i organizacji polskich.
\end{abstract}

Słowa kluczowe: Inflanty Polskie, Łotwa, Łatgalia, mniejszość polska, organizacje polskie, szkolnictwo polskie, spis powszechny

\begin{abstract}
This article presents the demographic, political and social situation of Poles in the contemporary Republic of Latvia. Based on the results of the Latvian census of 2011 the demographic perspective of the Polish minority has been discussed. After the year 1991 as a result of a favourable attitude of the Latvian authorities the Polish community regained the possibility of organisational activity. This study shows the process of reconstructing organizational structures of the Polish community. Also, the process of creating the Polish school system from the ground up has been shown as well as the current challenges faced by Polish schools connected both with their internal problems and a long-term policy of the Latvian authorities. This work also presents the major problems of Poles in Latvia and outlines possible perspectives for solving them with the help of Polish authorities and organisations.
\end{abstract}

Key words: Polish Livonia, Latvia, Latgale, Polish minority, Polish organisations, Polish school system, census

Związki Polaków z Łotwą mają długą i bogatą historię. Początek obecności polskiej na obszarze obejmującym dzisiejszą Republikę Łotewską można datować na wiek XVI, kiedy Inflanty weszły w skład Rzeczpospolitej. W la- 
tach 1918-1940, w okresie istnienia niepodległego państwa łotewskiego Polacy stali się jedną ze znaczących mniejszości narodowych. W okresie ZSRR ludność polska zamieszkująca Łotwę podlegała intensywnej rusyfikacji i sowietyzacji. Po rozpadzie ZSRR i przywróceniu w 1991 r. państwowości łotewskiej, Polacy zamieszkujący dotychczas w ŁSRR, stali się mieszkańcami Republiki Łotewskiej. Spowodowało to radykalną i pozytywną zmianę dla ludności polskiej. W konsekwencji tego wydarzenia społeczność polska mogła znów prowadzić działalność społeczną i kulturalną mającą na celu podtrzymywanie i kultywowanie polskości ${ }^{1}$.

Mniejszość polska na Łotwie rzadko jest przedmiotem badań naukowych. Artykuł jest próbą zapełnienia tej luki badawczej. Dla potrzeb niniejszego tekstu przeprowadzono badania źródłowe i analizę uzyskanych danych, a następnie na tej podstawie przedstawiono wnioski dotyczące funkcjonowania społeczności polskiej we współczesnej Łotwie².

W niepodległym państwie łotewskim pierwszy spis powszechny został przeprowadzony dopiero w 2000 r. Jego wyniki pokazały, że po Rosjanach, Białorusinach i Ukraińcach, Polacy byli czwartą pod względem liczebności mniejszościową grupą narodowościową. W spisie wykazano 59505 osób narodowości polskiej, co stanowiło 2,5\% ogółu ludności ${ }^{3}$. Mimo że w formularzach spisowych informacje o narodowości i języku ojczystym nie były zbierane przy pomocy pytań otwartych, lecz zamkniętych, gdzie należało wypełniać rubryki z gotowymi już propozycjami, wśród których nie było wyszczególnionej propozycji o narodowości lub języku polskim, wyniki można uznać za wiarygodne 4 .

Kolejny i ostatni jak dotychczas spis powszechny, a jednocześnie pierwszy po wejściu Łotwy do Unii Europejskiej, został przeprowadzony w 2011 r. Jego wyniki pokazały, że liczba osób narodowości polskiej wyniosła 44772 osoby, co stanowiło niespełna 2,2\% ogółu ludności, oraz że była ona nadal czwartą pod względem liczebności grupą narodowościową wśród

1 E. Jekabsons, Ziemie Łotwy między Wschodem a Zachodem Europy, Lublin 2007, s. 80.

2 Z uwagi na dwujęzyczność nazw geograficznych, autor używając w niniejszym artykule nazw geograficznych przyjął zasadę przedstawiania ich po raz pierwszy $w$ tekście $w$ postaci dwujęzycznej (polskiej i łotewskiej), a w dalszej części artykułu w wersji polskiej.

3 Latvijas Republikas Centrālā statistikas pārvalde, Latvijas Statistikas, Tautas skaitisana, 2012, http://data.csb.gov.lv/pxweb/lv/tautassk/tautassk_tsk2000/tsk_02.px/table/tableView Layout2/?rxid=992a0682-2c7d-4148-b242-7b48ff9fe0c2 [dostęp: 20 II 2018].

4 P. Eberhardt, Przemiany narodowościowe w państwach bałtyckich na przełomie XX $i$ XXI wieku, „Rocznik Nauk Społecznych”, t. 1(37) 2009, s. 95-113. 
mniejszości narodowych Łotwy ${ }^{5}$. Jednakże liczba ludności narodowości polskiej zmniejszyła się o 14773 osoby, co oznaczało spadek o $24 \%$ w stosunku do poprzedniego spisu. Stanowi to drastyczny spadek populacji i co ciekawe, umknął on uwadze badaczy.

Według spisu z 2011 r., terytorialnie skupiska ludności polskiej koncentrowały się $\mathrm{w}$ historycznym regionie Łatgalii (Latgale) i w stołecznej Rydze. Z łącznej liczby 44772 Polaków, 20806 osób zamieszkiwało w regionie Łatgalii, co stanowiło 46\% ich ogólnej liczby. Miejscami o największej liczbie Polaków były: miasto Dyneburg (Daugavpils) - 13278 osób, miasto Ryga - 12208, gmina Dyneburg - 3226, Krasław (Kraslava) - 1374, Jełgawa (Jelgava, do 1918 r. Mitawa) - 1083. W stosunku do ogółu ludności Łotwy, najwięcej ludności polskiej zamieszkiwało Łatgalię, gdzie stanowili oni 6,8\% mieszkańców. Miejscami o największym udziale ludności polskiej w stosunku do ogółu ludności były: miasto Dyneburg - 14,2\%, okręg Dyneburg - 12,8\%, gmina Krasław - 7,8\%, gmina Iłukszta (Ilukste) - 7,8\%. Generalnie większość zamieszkiwanych przez Polaków miejscowości znajduje się na terenie Łatgalii, a szerzej historycznych Inflant Polskich ${ }^{6}$.

W łotewskim spisie powszechnym z 2000 r., kwestionariusz, oprócz narodowości zbierał również informacje na temat języka ojczystego. Spośród osób deklarujących narodowość polską, jedynie 11529 osób $(19,4 \%)$ wskazało język polski jako ojczysty. Zdecydowanie największa liczba osób wśród deklarujących narodowość polską, podało język rosyjski jako język ojczysty - $34340(57,7 \%)$, a także łotewski $11727(19,7 \%)^{7}$. Oczywistym powodem takiego stanu rzeczy była intensywna rusyfikacja ludności polskiej w okresie władzy radzieckiej. Mimo upływu dekady od upadku ZSRR, skutki rusyfikacji utrzymywały się. Wyniki spisu powszechnego z $2011 \mathrm{r}$. potwierdziły, a wręcz jeszcze bardziej unaoczniły nieznajomość języka polskiego, a raczej zanik umiejętności posługiwania się językiem polskim przez ludność deklarującą narodowość polską. W spisie tym bowiem, w kwestionariuszu, zamiast pytania o język ojczysty znalazło się pytanie o język najczęściej używany $\mathrm{w}$ kontaktach domowych. Spowodowało to niejakie zamieszanie i utrudniło analizę danych, ponieważ część osób uważających nadal język polski

5 Latvijas Republikas Centrālā statistikas pārvalde, Latvijas Statistikas, 2011.gada skaitisanas rezultati, 2012, http://data.csb.gov.lv/pxweb/en/tautassk_11/tautassk_11__tsk2011/TSG11062.px/table/tableViewLayout2/?rxid=747cf090-c723-4ee2-a2f4-f7929c48915f [dostęp: 20 II 2018].

6 Ibidem.

7 Ibidem. 
za ojczysty, nie używała go w kontaktach domowych. Według spisu z 2011 r., jedynie 1425 osób (3,6\%) deklarujących narodowość polską, podało język polski jako najczęściej używany w kontaktach domowych. Ponad 30 tys. osób deklarujących narodowość polską podało język rosyjski, ok. 8 tys. język łotewski, a ponad 4,7 tys. nie potrafiło określić języka najczęściej używanego w domu ${ }^{8}$.

Spis powszechny z $2011 \mathrm{r}$. zbierał też dane na temat wykształcenia, w tym również w obrębie poszczególnych grup narodowościowych. W grupie narodowości polskiej znajdowało się 8000 osób (18\%) z wykształceniem wyższym i 9557 osób (21\%) z wykształceniem podstawowym lub niższym. Wskaźniki te dla ogółu ludności kraju wynosiły odpowiednio $20 \%$ i 19\%. Pokazało to niestety, że społeczność polska była generalnie słabiej wykształcona i wypadła w tych statystykach gorzej od innych narodowości ${ }^{9}$.

Analiza tych danych pokazuje, że od czasu rozpadu ZSRR i powstania państwa łotewskiego, oraz co za tym idzie, odbudowy szkolnictwa polskiego, niestety nie nastąpił wśród społeczności polskiej zauważalny postęp w dziedzinie znajomości i używania na co dzień języka ojczystego. Większość ludności polskiej posługuje się językiem rosyjskim i jest to $\mathrm{w}$ zasadzie łatwo wytłumaczalne przez półwiekową rusyfikację, ale również przez to, że Polacy zamieszkują właśnie te obszary Łotwy, gdzie dominuje język rosyjski. Zarówno Ryga jak i Łatgalia, gdzie mieszkają Polacy, to miejsca i obszary wieloetniczne, gdzie przeważa jednak ludność rosyjskojęzyczna. Dodatkowym czynnikiem jest bardzo duża liczba tzw. małżeństw mieszanych. Można sądzić, że w takich rodzinach, gdzie jedno z rodziców jest pochodzenia polskiego, a drugie rosyjskiego, językiem rodziny staje się rosyjski, jako język kultury dominującej oraz dawny język urzędowy.

Ma to jeszcze jeden negatywny skutek dla ludności polskiej starszego pokolenia na tych terenach. Nie zna ona bowiem często także języka łotewskiego, będącego językiem urzędowym w kraju. Co za tym idzie, takie osoby, bez znajomości języka łotewskiego nie uzyskały obywatelstwa łotewskiego, a $\mathrm{w}$ konsekwencji nie posiadają prawa wyborczego, prawa do nabywania ziemi i zajmowania stanowisk $\mathrm{w}$ administracji państwowej. Ustawa o obywatelstwie z 1994 r. przewidywała bowiem, że obywatelami Łotwy są tylko te osoby i ich potomkowie, które posiadały obywatelstwo łotewskie w 1940 r., a osoby nie spełniające tego kryterium, mogły ubiegać się o nadanie obywatelstwa przy spełnieniu szeregu wymogów, jednym z których była znajomość

8 Ibidem.

9 Ibidem. 
języka łotewskiego potwierdzona egzaminem państwowym. Część ludności polskiej nie spełniała żadnego z tych warunków, pozwalających uzyskać obywatelstwo państwa łotewskiego. Według niektórych szacunków, w takiej sytuacji może znajdować się nawet kilkanaście tysięcy osób ${ }^{10}$. Na podstawie badań przeprowadzonych wśród ludności polskiej w 2007 r. w Dyneburgu wynikało, że ok. $25 \%$ Polaków nie posiadało obywatelstwa łotewskiego. Jednocześnie te same badania potwierdzały fakt słabej znajomości języka polskiego, oraz to, że najważniejszym wyznacznikiem polskości jest pochodzenie, a dopiero $w$ dalszej kolejności czynniki kulturowe, jak znajomość języka czy kultury polskiej ${ }^{11}$.

Analizując dane demograficzne, należy w tym miejscu zauważyć, iż na tle innych mniejszości narodowych Łotwy, ludność polskiego pochodzenia wykazywała aż do spisu z roku 2011 wyjątkową stabilność stanu posiadania. Poczynając od spisów międzywojennych, poprzez spisy z okresu ZSRR, aż do spisu z roku 2000, zawsze liczyła ona ok. 60 tys. osób. Spis z 2011 r. pokazujący drastyczny spadek ilości ludności polskiej, w tak krótkim badanym okresie, między rokiem 2000 a 2011, stanowi tym bardziej zadziwiającą anomalię. Nie zostały przeprowadzone dotychczas żadne badania, które próbowałyby wyjaśnić to zjawisko. Zdaniem przedstawicieli organizacji polskich istniejących na Łotwie, wyniki tego spisu zaniżyły liczbę Polaków, a za przyczynę uznano usunięcie z paszportu rubryki „narodowość” ${ }^{12}$. Wyjaśnienie to należałoby jednak uznać za niewystarczające, chociażby z tego powodu, że znaczna część Polaków na Łotwie nie posiada łotewskich paszportów. Rzeczywiste przyczyny takiego znaczącego obniżenia się liczby osób deklarujących narodowość polską nie są znane. Można postawić hipotezę, że mogą być następujące: ruchy migracyjne, niski przyrost naturalny, duża liczba małżeństw mieszanych na obszarze zamieszkiwanym przez ludność polską i wreszcie zmiany w kwestionariuszu spisowym.

Wydaje się, że ruchy migracyjne i niski przyrost naturalny nie w pełni wyjaśniają zaskakujący spadek liczby osób deklarujących narodowość polską. Ogólna liczba ludności Łotwy zmniejszyła się wprawdzie w 2011 r. w stosunku do spisu z 2000 r., ale był to spadek znacząco mniejszy, bo o 13\%. Liczba ludności wśród innych mniejszości narodowych również zmniejszyła

10 K. Składowski, Sytuacja ludności polskiej na Ukrainie i Łotwie, [w:] Sytuacja ludności polskiej na Wschodzie w świetle obowiąującego prawa i praktyki, red. D. Górecki, Toruń 2009, s. 137-156.

11 J. Kurczewski, Polacy nad Dźwina - wyniki badań ankietowych 2007 roku, [w:] Polacy nad Dźwina, red. J. Kurczewski, M. Fuszara, Warszawa 2009, s. 19-59.

12 K. Leśniewska-Napierała, Geograficzno-polityczne uwarunkowania sytuacji mniejszości polskiej na Litwie i Łotwie po 1990 roku, Łódź 2015, s. 115. 
się w badanym okresie, ale również był to spadek procentowo mniejszy. Ponadto w przypadku ludności rosyjskiej i białoruskiej było to zjawisko spowodowane zupełnie innymi, politycznymi przyczynami. Poza tym, jak już wspomniano, w odróżnieniu od innych mniejszości narodowych, w szczególności rosyjskiej, która w różnych okresach podlegała dużym zmianom, ludność polska charakteryzowała się dotychczas wyjątkową stabilnością liczebności. Innym czynnikiem, który należałoby wziąć pod uwagę, była zmiana w formularzach spisowych. W spisie z 2011 r., inaczej niż 2000 r., w kwestionariuszu, zamiast pytania o język ojczysty znalazło się bowiem zapytanie o język najczęściej używany w domu. Mogło to spowodować pewne zamieszanie i utrudniać samoidentyfikację, bowiem część osób deklarujących narodowość polską i język polski jako ojczysty, nie używa go na co dzień, ani w domu. Jednak ta przyczyna również wydaje się wątpliwa i mniej istotna, bowiem jak wynika $\mathrm{z}$ analiz danych ze spisów powszechnych, w przypadku Polaków na Łotwie, język nie stanowi dla nich podstawowego wyznacznika tożsamości narodowej. Inną przyczyną, którą jak się wydaje, należałoby wziąć poważnie pod uwagę, analizując problem spadku liczby osób deklarujących narodowość polską, jest zjawisko występowania tzw. małżeństw mieszanych na obszarze zamieszkiwanym przez mniejszość polską. Zarówno Ryga, jak i Dyneburg i generalnie Łatgalia, gdzie mieszkają Polacy, to obszary wieloetniczne, więc występowanie małżeństw i rodzin wielonarodowych jest tu zjawiskiem powszechnym. Przeważa jednak ludność rosyjskojęzyczna, a Polacy i nawet Łotysze są często w mniejszości. Można zakładać, że w takim otoczeniu, w rodzinach gdzie jedno z rodziców jest pochodzenia rosyjskiego, język i kultura rosyjska stają się w sposób naturalny bardziej atrakcyjne i dominują. Podobne zjawisko występuje zresztą również, w rodzinach polsko-łotewskich, gdzie język łotewski jako język urzędowy dominuje nad polskim. Jednak dotychczas zjawisko posługiwania się innym językiem nie powodowało wśród Polaków na Łotwie utraty polskiej tożsamości kulturowej i narodowej. Wydaje się, że obecnie postępuje proces utraty nie tylko języka polskiego, ale także proces utraty tożsamości kulturowej i narodowej. Przypuszczać można, że dla części ludności pochodzenia polskiego, szczególnie $\mathrm{w}$ rodzinach mieszanych, kultura polska stała się mniej atrakcyjna, co powoduje rusyfikację lub lettonizację. Dla pełnego zweryfikowania przedstawionych hipotez, należałoby jednak przeprowadzić bardzo szerokie i kompleksowe badania socjologiczne.

Przywrócenie niepodległości państwa łotewskiego było wydarzeniem przełomowym i bardzo korzystnym dla zamieszkujących Łotwę Polaków. Już pod koniec istnienia ZSRR udało się wznowić działalność organizacji 
społeczno-kulturalnych mniejszości polskiej. W 1978 r. powstał Klub Przyjaciół Polski przy Domu Kultury Budowlanych w Rydze, gdzie od razu zaczęły odbywać się występy i koncerty w języku polskim. Przy klubie został zorganizowany zespół tańca polskiego „Polonez”, następnie również klub otrzymał nazwę "Polonez". Celem klubu, według regulaminu, było zapoznanie się z najcenniejszymi dziełami sztuki i literatury polskiej, klasycznej i współczesnej oraz szerzenie polskości na Łotwie. Pierwszym prezesem klubu był Bolesław Gołubiec ${ }^{13}$. W 1988 r. powstało Towarzystwo Społeczno-Kulturalne „Promień" w Dyneburgu i Stowarzyszenie Społeczno-Kulturalne Polaków na Łotwie (SSKPŁ) w Rydze.

Polacy uczestniczyli też w działalności Frontu Ludowego, organizacji która przyczyniła się do restytuowania państwowości łotewskiej. W jego działalność była zaangażowana między innymi Ita Kozakiewicz, członek Rady Najwyższej ŁSRR, która ogłosiła deklarację niepodległości Łotwy. Ona też była inspiratorką powołania do życia Łotewskiej Asocjacji Towarzystw Mniejszości Narodowych i była wiceprezesem tej organizacji. Jako orędowniczka praw wszystkich mniejszości narodowych na Łotwie, jednocześnie uważała, że najlepszym gwarantem praw mniejszości polskiej będzie niepodległe, suwerenne, demokratyczne państwo łotewskie ${ }^{14}$. Dzięki propaństwowej i niepodległościowej działalności Ity Kozakiewicz Łotysze zaczęli postrzegać Polaków jako sojuszników w swojej walce o niepodległość15. W konsekwencji, również w późniejszym okresie mniejszość polska cieszyła się poparciem lub przynajmniej życzliwą neutralnością władz łotewskich, w odróżnieniu od mniejszości rosyjskiej, która zwykle postrzegana była i jest, jako nieprzyjazna i nastawiona konfrontacyjnie w stosunku do państwowości łotewskiej ${ }^{16}$.

W styczniu 1990 r. w Rydze odbył się pierwszy Zjazd Polaków z Łotwy. W czasie zjazdu postanowiono, że SSKPŁ zostanie przekształcony w Związek Polaków na Łotwie (ZPŁ). Tym samym utworzono ogólnokrajową organizację mniejszości polskiej, będącą sukcesorem i nawiązującą do międzywojennej organizacji o tej samej nazwie. Pierwszym prezesem została Ita Kozakiewicz. Od razu powstało osiem oddziałów regionalnych ZPŁ, które

13 D. Malzuba, 35 lat działalności Klubu Kultury Polskiej „Polonez", http://www.polonia.lv/ news.php?lang=2\&cPath=1\&page=3\&new_id=213 [dostęp: 12 II 2018].

14 R. Lebedek, 20 lat bez Ity Kozakiewicz, „Polak na Lotwie” 2010, nr 3 (93).

15 E. Jekabsons, Polska mniejszość narodowa na Łotwie. Krótka charakterystyka i zarys działalności, „Wiadomości Historyczne" 2013, nr 4, s. 21-26.

16 M. Kowalski, Ludność polska w wieloetnicznych regionach Łotwy, Litwy i Białorusi, „Studia z Geografii Politycznej i Historycznej" 2013, nr 2, s. 225. 
znajdowały się w Rydze, Dyneburgu, Krasławiu, Jełgawie/Mitawie, Windawie (Ventspils), Rzeżycy (Rezekne), Lipawie (Liepaja) i Dobele (Dobele). Po powstaniu ZPŁ, dotychczasowy „Promien”" z Dyneburga przekształcił się właśnie w regionalny oddział organizacji. Głównymi celami organizacji, określonymi w statucie były w tym okresie integracja Polaków, odnowa życia religijnego, ochrona polskiego dziedzictwa kulturalnego i przede wszystkim odbudowa szkolnictwa polskiego ${ }^{17}$. Obecnie związek liczy ok. 3 tys. członków i działa już 15 oddziałów regionalnych ZPŁ. Do poprzednio funkcjonujących dołączyły nowe oddziały w następujących miastach: Jurmała (Jurmala), Lucyn (Ludza), Bowsk (Bauska), Tukum (Tukums), Jakubowo (Jekabpils), Kieś (Cesis), Małta (Malta). Po tragicznej śmierci pierwszej prezes związku Ity Kozakiewicz w 1990 r., kolejnymi prezesami byli Robert Sieliszka, Maria Szymańska, Maria Kudriacewa, Wanda Krukowska i obecnie Ryszard Stankiewicz. Corocznie odbywają się zjazdy związku, a oddziały regionalne mają dużą samodzielność ${ }^{18}$.

Oddział ZPŁ w Dyneburgu jest największy i najbardziej prężny. Dysponuje własnym budynkiem Domu Polskiego, gdzie w 1997 r. zostało powołane Centrum Kultury Polskiej (CKP). Dyrektorem Domu Polskiego i Centrum Kultury Polskiej jest obecnie Żanna Stankiewicz ${ }^{19}$. Działalność CKP jest niezwykle bogata i zajmuje szczególne miejsce w aktywności całej społeczności polskiej na Łotwie. Do głównych celów działalności CKP można zaliczyć popularyzację kultury polskiej oraz wiedzy o niej, podtrzymywanie tradycji ludowych, integrację mniejszości polskiej, utrzymywanie związków z Polską. CKP organizuje festiwale, koncerty, wystawy, spotkania oraz inne projekty. Centrum współpracuje też z organizacjami i środowiskami polonijnymi w dziedzinie oświaty, nauki i kultury. Inną ważną formą działalności CKP jest współpraca kulturalna i oświatowa ze szkołami polskimi oraz terenowymi oddziałami Związku Polaków. Współpraca ta owocuje wymianą zespołów artystycznych, a także realizacją wielu wspólnych projektów. W październiku 2017 r. Centrum Kultury Polskiej w Dyneburgu uroczyście obchodziło swoje dwudziestolecie ${ }^{20}$.

17 Statut Związu Polaków na Łotwie, Ryga 2005.

18 W. Krukowska, O Stowarzyszeniu Związek Polaków na Łotwie, http://www.polonia.lv/index. php?lang=2\&cPath=717\&txt_id=22 [dostęp: 12 II 2018].

19 Stowarzyszenie Wspólnota Polska, Organizacje polonijne, http://wspolnotapolska.org.pl/po lonia/informacje.php?id=67660/ [dostęp: 12 II 2018].

20 Centrum Kultury Polskiej w Daugavpils, O nas, http://ckp.lv/index.php?option=com_con tent\&view=article\&id=11\&Itemid=2\&lang=pl [dostęp: 12 II 2018]. 
Przy Centrum prowadzi działalność bardzo wiele instytucji kulturalnych i oświatowych jak: kółka teatralne, zespół tańca ludowego „Kukułeczka”, zespół wokalny „Barwy Daugawy”, chór „Promien”, dziecięcy klub „Szkolna Chatka”, Klub Polskich Kobiet, Klub Seniora, biblioteka polska „Promień” 21.

Zespół wokalny „Barwy Daugawy” powstał w 2002 r., mając na celu rozwijanie umiejętności wokalnych u dzieci, rozwój potencjału twórczego oraz zainteresowania sztuką, muzyką, a także poezją polskich i łotewskich autorów. Repertuar zespołu składa się z piosenek ludowych polskich oraz łotewskich, utworów patriotycznych i estradowych, pieśni religijnych. Obecnie kierownikiem zespołu jest Stanisław Jakowenko. Zespół „Barwy Daugawy” jest częstym gościem koncertów, wieczorów artystycznych oraz imprez wyjazdowych Centrum Kultury Polskiej. Wokaliści zespołu są stałymi uczestnikami oraz laureatami krajowego oraz międzynarodowego konkursu piosenki estradowej na Lotwie 22 .

Zespół Tańca Ludowego „Kukułeczka” powstał w 1991 r. i ma na swoim koncie ponad 300 koncertów. W repertuarze ma ludowe tańce polskie oraz łotewskie. „Kukułeczka” jest stałym uczestnikiem Festiwali Kultury Polskiej oraz Festiwali Mniejszości Narodowych organizowanych na Łotwie. Regularnie uczestniczy w ogólnołotewskim Święcie Tańca. Zespół brał udział także w wielu festiwalach w Polsce, m.in. Festiwalach Kultury Kresowej w Mrągowie, Festiwalach Zespołów Polonijnych Krajów Nadbałtyckich „Bursztynowa Kolia Bałtyku” w Elblągu, Międzynarodowym Festiwalu Folkloru na Kaszubach, Polonijnych Festiwalach Dziecięcych Zespołów Folklorystycznych w Iwoniczu-Zdroju i Światowym Festiwalu Polskiego Folkloru w Rzeszowie, Międzynarodowych Festiwalach Dziecięcych Zespołów Folklorystycznych Mniejszości Narodowych w Węgorzewie i Pieńsku, Festiwalu „Kwiaty Polskie” w Niemenczynie (Litwa), Festiwalu „Sławiański Bazar" w Witebsku (Białoruś) oraz Festiwalach Folkloru w Szwecji. W 2006 r. Zespół Tańca Ludowego „Kukułeczka” otrzymał nagrodę TVP Polonia "Za sławienie Polski i Polskości." Symbolem nagrody jest statuetka Fryderyka Chopina. W maju 2011 r. zespół uroczyście świętował swoje dwudziestolecie ${ }^{23}$.

21 Ibidem, Zespoły, http://ckp.lv/index.php?option=com_content\&view=section\&layout=blog \&id=5\&Itemid=4\&lang=pl [dostęp: 12 II 2018].

22 Ibidem, Zespót wokalny „Barwy Daugawy”, http://www.ckp.lv/index.phpoption=com_con tent\&view=article\&id=35\&Itemid=52\&lang=pl [dostęp: 12 II 2018].

23 Ibidem, Zespół Tańca Ludowego „Kukułeczka”, http://ckp.lv/index.php?option=com_content\& view=article\&id=24\&Itemid=51\&lang=pl [dostęp: 12 II 2018]. 
Chór „Promień” został założony w 1988 r. przez Halinę Bakalar-Czumaczenko i Gertrudę Kiewicz. W chwili obecnej kierują i opiekują się chórem Regina Krukowska i Maria Jurkowa. Zespół występuje na koncertach i festiwalach w Łotwie, Litwie i Polsce, między innymi na Festiwalu Kultury Polskiej, Festiwalu Pieśni Religijnej w Krasławiu, w koncertach organizowanych w ramach tygodnia Kultury Słowiańskiej. W programie chóru są polskie oraz łotewskie pieśni patriotyczne, religijne, ludowe. W 2018 r. zespół obchodził uroczyście jubileusz 30-lecia działalności ${ }^{24}$.

W 2017 r. najważniejszymi wydarzeniami kulturalnymi organizowanymi w CKP w Dyneburgu były: VIII Międzynarodowy Festiwal Polskiego Folkloru „Polski Folklor w Łatgalii”, Konkurs Polskiej i Łotewskiej Piosenki Estradowej, koncert z okazji 20-lecia CKP, koncert z okazji Niepodległości Polski i Łotwy, wystawa Katarzyny Grocholskiej, wystawa rzeźby i grafiki Romualda Gibowskiego, wystawy fotograficzne Julii Siwaszowej i studium „Ezerzeme" 25 .

Najstarszą jednak instytucją kulturalną społeczności polskiej na Łotwie jest mieszczący się w Rydze Klub Kultury "Polonez". Jego początki sięgają 1978 r., kiedy Wanda Puke założyła Klub Przyjaciół Polski „Polonez”. Stał się on zalążkiem i inspiracją dla powstałego w 1988 r. Towarzystwa Kultury Polskiej, a następnie Związku Polaków na Łotwie. Obecnie ryski Dom Kultury „Polonez” jest głównym ośrodkiem społeczności polskiej w stolicy Łotwy. Przez wiele lat jego prezesem był zasłużony działacz Edward Fiskowicz. „Polonez” jest organizatorem i bierze aktywny udział w różnorodnych imprezach związanych z kulturą i sztuką polską, tak na Łotwie, jak i w Polsce. Klub aktywnie współpracuje ze Związkiem Polaków na Łotwie, Asocjacją Towarzystw Kultur Narodowych im. Ity Kozakiewicz, Ambasadą Rzeczypospolitej Polskiej na Łotwie, różnymi instytucjami kulturalnymi w Polsce oraz ministerstwami kultury Polski i Łotwy. Zespoły i soliści „Poloneza” występowali nie tylko na Łotwie, ale także w różnych miastach Litwy, Estonii i Polski. Chór „Polonez” oraz jego soliści są laureatami wielu konkursów i festiwali, na przykład światowego festiwalu chórów w Koszalinie, festiwalu Marii Konopnickiej w Mokrych Górach i innych. W 2013 r. odbył się uroczysty koncert z okazji 35-lecia Klubu Kultury Polskiej „Polonez” w Rydze. Wśród gości

24 Ibidem, Chór „Promień", http://ckp.lv/index.php?option=com_content\&view=article\&id= 34\&Itemid=49\&lang=pl [dostęp: 12 II 2018].

25 Ibidem, VIII Międzynarodowy Festiwal Polskiego Folkloru „Polski Folklor w Łatgalii", http:// www.ckp.lv /index.php?option=com_content\&view=article\&id=535\&Itemid=364\&lang=pl [dostęp: 12 II 2018]. 
koncertu byli ambasador RP na Łotwie z małżonką, przewodniczący Stowarzyszenia Towarzystw Mniejszości Narodowych na Łotwie, przedstawiciel Ministra Kultury RŁ. W roku 2017 największym wydarzeniem mającym miejsce w klubie „Polonez" był XXI Międzynarodowy konkurs polskiej i łotewskiej piosenki estradowej ZAKR-201726.

W 1998 r. w Rydze powstał Związek Młodych Polaków na Łotwie (ZMPŁ). Podstawowym celem organizacji była integracja polskiej młodzieży na Łotwie, wzbudzenie $\mathrm{w}$ niej zainteresowania kulturą polską, organizowanie spotkań, kursów języka polskiego, wycieczek integracyjnych i wizyt w Polsce. Pierwszym prezesem, organizatorem i jednym z założycieli ZMPŁ była Anna Osite. W 2002 r. w Rydze, przy Łotewskiej Akademii Kultury powstało pierwsze w krajach bałtyckich Centrum Informacji Kultury i Języka Polskiego. Założycielem i kierownikiem była delegowana z Polski do Ambasady RP w Rydze, a będąca wówczas również pracownikiem naukowym Łotewskiej Akademii Kultury dr Monika Michaliszyn, która współuczestniczyła w pracach ZMPŁ ${ }^{27}$.

Z innych organizacji społeczno-kulturalnych mniejszości polskiej wspomnieć warto o założonym w 2005 r. w Dyneburgu Klubie Stypendystów „Semper Polonia”. Klub działa przy Centrum Kultury Polskiej i zajmuje się popularyzacją i propagowaniem kultury polskiej, szczególnie wśród młodzieży 28. W 2011 r. w Dyneburgu powstało Stowarzyszenie "Odrodzenie Inflant". Założycielami byli absolwenci filologii polskiej Uniwersytetu w Dyneburgu, a jako cel działalności wskazano prowadzenie badań historycznych i odbudowa tradycji i tożsamości Inflant Polskich ${ }^{29}$.

Jednym z pierwszych wymiernych i prawdopodobnie najważniejszych efektów organizacyjnych odradzania się mniejszości polskiej na Łotwie, była stopniowa odbudowa szkolnictwa polskiego. Pierwsze tego oznaki dały się zauważyć już w okresie schyłkowym ZSRR. Było to możliwe dzięki porozumieniu między resortami edukacji Łotewskiej SSR i PRL z 1989 r. Przewidywało one wszechstronną współpracę w zakresie rozwoju nauczania ję-

26 Ambasada Rzeczypospolitej Polskiej w Rydze, Jubileusz Klubu Kultury Polskiej „Polonez” $w$ Rydze, https://ryga.msz.gov.pl/pl/aktualnosci/jubileusz_klubu_kultury_polskiej_polonez __w_rydze;jsessionid=DB60966FA4A0373C5CEE2D1361740A35.cmsap1p [dostęp: 20 II 2018].

Związek Młodych Polaków na Łotwie, Historia powstania i działalności Związku, http:// www.polonia.lv/index.php?lang=2\&cPath=1\%7C3\&txt_id=2 [dostęp: 25 II 2018].

28 Fundacja Semper Polonia, Stypendia i programy dla Polonii, http://www.semperpolonia.pl/ programy-fundacji/absolwent/article/dyneburg-lotwa/ [dostęp: 25 II 2018].

29 Ambasada Rzeczypospolitej Polskiej w Rydze, Polacy na Łotwie, http://www.ryga.msz.gov. $\mathrm{pl} / \mathrm{pl} /$ aktualnosci/stowarzyszenie_odrodzenie_inflant [dostęp: 25 II 2018]. 
zyka polskiego na Łotwie. W 1989 r., w Rydze, z inicjatywy Ity Kozakiewicz, w szkole średniej została utworzona pierwsza polska klasa. Do pracy w niej przybyła grupa nauczycieli z Polski. Dzięki zabiegom działaczy Ośrodka Kulturalno-Oświatowego „Promień", również w Dyneburgu powstały polskie klasy. W innych ośrodkach zorganizowano tzw. szkoły niedzielne. Pierwsza taka szkoła powstała w 1989 r. w Jełgawie, a następne w Windawie, Krasławiu, Lipawie, Iłukszcie, Kiesi. Trzeba podkreślić pozytywny stosunek do tych inicjatyw strony łotewskiej, gdyż wszystkie te szkoły były finansowane przez Ministerstwo Oświaty Łotwy. Jednak w początkowym okresie wielkimi przeszkodami w rozwoju polskiego szkolnictwa był brak nauczycieli, podręczników, programów nauczania, pomocy dydaktycznych i lokali ${ }^{30}$.

Po 1991 r., kiedy przywrócona została państwowość łotewska, nastąpiło znaczne przyspieszenie $\mathrm{w}$ procesie rozwoju szkolnictwa polskiego. Generalne zasady i podstawy prawne powstawania i funkcjonowania szkół polskich na Łotwie regulowało ustawodawstwo łotewskie i międzypaństwowe umowy dwustronne. Stało się to możliwe dzięki umowie między rządami Rzeczypospolitej Polskiej i Republiki Łotewskiej z 1992 r., a także porozumieniom między ministerstwami Edukacji Narodowej RP i Edukacji RŁ, które przewidywały współpracę kulturalną, naukową i oświatową oraz wsparcie dla szkół mniejszości polskiej na wszystkich poziomach nauczania ${ }^{31}$.

Pierwsza polska szkoła rozpoczęła działalność 1 września 1991 r. w Rydze i nadano jej imię Ity Kozakiewicz. Większość nauczycieli oddelegowanych przez Ministerstwo Edukacji Narodowej RP, przybyła z Polski, co stało się w przyszłości stałą praktyką 32. Również 1 września 1991 r., po ponad czterdziestoletniej przerwie została utworzona Polska Szkoła w Dyneburgu, która początkowo składała się z klas eksperymentalnych w jednej ze szkół rosyjskich. Dopiero w 1998 r. uzyskała ona tzw. akredytację i status samodzielnej szkoły średniej ${ }^{33}$. Od 1993 r. działa też w Dyneburgu polskie przedszkole. W 1991 r. rozpoczęła działalność polska szkoła początkowa w Kra-

30 R. Runiewicz-Jasińska, Oświata polska w niepodległej Litwie, Łotwie i Estonii w latach 1991-2001, Wilno 2003, s. 245-246.

31 Umowa między Rządem RP a Rządem RE o wspótpracy kulturalnej, naukowej i oświatowej z 01.07.1992, Dz.U. 1993 r., nr 114, poz. 504.

32 Rozporządzenie Ministra Edukacji Narodowej RP $w$ sprawie zasad wspomagania nauczania historii, geografii i języka polskiego wśród Polonii oraz zakresu świadczeń przystugujących nauczycielom polskim skierowanym w tym celu do pracy za granica, Dz.U. 1992 r., nr 63, poz. 316.

33 R. Runiewicz-Jasińska, op. cit., s. 245-246. 
sławiu. W kolejnych latach polskie placówki szkolne powstawały w Rzeżycy, Jakubowie, Jełgawie ${ }^{34}$.

Obecnie szkolnictwo polskie na Łotwie dysponuje siedmioma placówkami, w których uczy się 1300-1400 dzieci. Są to: szkoła im. Ity Kozakiewicz w Rydze (szkoły podstawowa i średnia), szkoła im. Józefa Piłsudskiego w Dyneburgu (szkoła podstawowa i gimnazjum), szkoła im. Stefana Batorego w Rzeżycy (szkoła podstawowa i gimnazjum), szkoła im. Rodu hr. Platerów w Krasławiu (szkoła podstawowa), przedszkole im. Jana Platera Gajewskiego w Dyneburgu ${ }^{35}$.

Szkoły prowadzą też zajęcia pozalekcyjne o charakterze kulturalnym i artystycznym. Wśród szkolnych zespołów artystycznych najbardziej znane są chóry: „Polonez” i „Wisła” z Rygi, „Promień” z Dyneburga, „Jutrzenka” z Rzeżycy, „Strumien”" z Krasławia, które często zdobywają nagrody na międzynarodowych konkursach ${ }^{36}$.

Najstarsza polska szkoła im. Ity Kozakiewicz w Rydze kształci obecnie ok. 400 uczniów. Zajęcia prowadzą nauczyciele miejscowi i pedagodzy z Polski. Zajęcia odbywają się w językach polskim i łotewskim. Nauka odbywa się na trzech poziomach: przedszkole, szkoła podstawowa, szkoła średnia. Program nauczania obejmuje dodatkowo zajęcia z literatury, historii i geografii Polski. Nowoczesny budynek szkoły wyposażony jest w salę sportową, aulę, pracownię komputerową i inne gabinety. Szkoła działa w lokalnym systemie oświaty (jest nadzorowana przez lokalne władze oświatowe) i jest finansowana jest przez lokalne władze. Funkcję dyrektora pełni obecnie Krzysztof Szyrszeń ${ }^{37}$.

Druga najstarsza polska szkoła im. Józefa Piłsudskiego w Dyneburgu kształci obecnie ponad 300 uczniów. W oficjalnym rankingu, spośród 18 szkół w mieście należy do czwórki najlepszych. Zajęcia odbywają się w językach polskim i łotewskim. Dodatkowo prowadzone są zajęcia z języka rosyjskiego. Obecnie dyrektorką szkoły jest Halina Smulko ${ }^{38}$.

\footnotetext{
34 Ibidem, s. 255-259.

35 Ambasada Rzeczypospolitej Polskiej w Rydze, Polacy na Łotwie, http://www.ryga.msz.gov. $\mathrm{pl} / \mathrm{pl} /$ wspolpraca_dwustronna/polacy/szkoly/szkoly [dostęp: 20 II 2018].

36 Stowarzyszenie Wspólnota Polska, Organizacje polonijne, http://wspolnotapolska.org.pl/ polonia/informacje.php?id=463/ [dostęp: 25 II 2018].

37 Ibidem.

38 E. Mokrzecka, Dyrektorka polskiego gimnazjum w Dyneburgu: Polak i Łotysz to bracia, „Znad Wilii", 23.06.2015, http://zw.lt/tag/panstwowe-gimnazjum-polskie-im-j-pilsudskiego-w-dyne burgu/ [dostęp: 20 II 2018].
} 
Największą polską placówką oświatową na Łotwie stała się od kilku lat szkoła im. Stefana Batorego w Rzeżycy (szkoła podstawowa i gimnazjum). Jest ona obecnie jedną z najlepszych i najdynamiczniej rozwijających się w regionie. W pierwszym roku istnienia szkoła liczyła zaledwie ok. 40 uczniów, a obecnie uczęszcza do niej ponad 500 dzieci. W 2018 r. obchodziła jubileusz 25-lecia działalności. Założycielką i dyrektorką szkoły od początku jej istnienia jest Walentyna Szydłowska. Dowodem uznania dla jej pracy są odznaczenia państwowe, zarówno łotewskie (Order Trzech Gwiazd Klasy Pierwszej jak i polskie (Złoty Krzyż Zasługi, Krzyż Kawalerski Orderu Zasługi) ${ }^{39}$.

Analizując szczegółowo dane demograficzne ze spisu powszechnego z 2011 r. i aktualną liczebność uczniów szkół polskich można stwierdzić niestety, że uczęszcza do nich jedynie ok. $30 \%$ populacji dzieci narodowości polskiej. Biorąc zaś pod uwagę, że do szkół polskich uczęszcza zapewne również pewna liczba dzieci innych narodowości, odsetek ten będzie jeszcze mniejszy ${ }^{40}$. Trzeba w tym miejscu zaznaczyć, że większość szkół polskich zajmuje wysokie miejsca $\mathrm{w}$ rankingach dotyczących poziomu nauczania, więc przyczyną takiego stanu rzeczy nie jest ich niski poziom. To zjawisko również zasługuje na uwagę socjologów.

Od dłuższego czasu polityka państwa łotewskiego przykłada coraz większą wagę do nauczania w języku urzędowym. Od roku 1995 rozpoczęto reformę programów szkół mniejszości narodowych, wprowadzając stopniowo język łotewski jako język nauczania. Począwszy od roku szkolnego 1995/1996 w szkołach podstawowych wprowadzono obowiązkowe nauczanie przynajmniej dwóch przedmiotów w języku łotewskim ${ }^{41}$. Od 2004 r. zgodnie ze znowelizowanym w 1998 r. prawem edukacyjnym, nauczanie na Łotwie w szkołach mniejszości narodowych odbywa się w systemie bilingwalnym (dwujęzycznym). Do wyboru były cztery modele zaprojektowane przez ministerstwo. Szkoły dokonywały samodzielnego wyboru kierując się lokalnymi uwarunkowaniami i opinią społeczności. Część zajęć prowadzi się obowiąz-

39 Ambasada Rzeczypospolitej Polskiej w Rydze, Dyrektor Walentyna Szydłowska uhonorowana Orderem Trzech Gwiazd, 5.05.2017, https://ryga.msz.gov.pl/pl/aktualnosci/dyrektor_walen tyna_szydlowska_uhonorowana_orderem_trzech_gwiazd_1 [dostęp: 20 II 2018].

40

W 2011 r. liczba osób narodowości polskiej w wieku 5-19 lat wyniosła 4370, a liczba uczniów szkół polskich w tym samym czasie ok. 1400 osób. Zob.: Latvijas Republikas Centrālā statistikas pārvalde, Latvijas Statistikas, 2011.gada skaitisanas rezultati, 2012, http:// data.csb.gov.lv/pxweb/en/tautassk_11/tautassk_11_tsk2011/TSG11-06.px/table/tableView Layout2/?rxid=992a0682-2c7d-4148-b242-7b48ff9fe0c2 [dostęp: 20 II 2018].

41 Latvijas Republikas Arlietu Ministrija, Introduction of national minority education, http:// www.mfa.gov.lv/en/policy/society-integration/minority-education-in-latvia/implementa tion-of-national-minority-education [dostęp: 25 II 2018]. 
kowo w języku łotewskim, a część w języku mniejszości, zależnie od modelu $\mathrm{w}$ różnych proporcjach. Zwykle jest to ok. $60 \%$ zajęć prowadzonych w języku łotewskim ${ }^{42}$.

22 marca 2018 r. parlament łotewski uchwalił poprawki do ustawy edukacyjnej, które mają wprowadzać stopniowo dalsze zmiany zmierzające w takim kierunku, aby nauczanie na wyższych szczeblach systemu edukacji odbywało się już wyłącznie w języku urzędowym. Ustawa w nowym brzmieniu wejdzie w życie 1 września 2019 r. Docelowo od 1 września 2022 r. edukacja będzie odbywać się według następujących zasad: w okresie przedszkolnym nauczanie dwujęzyczne, w szkołach powszechnych w klasach 1-6 nie mniej niż 50\% przedmiotów w języku łotewskim, w szkołach powszechnych w klasach 7-9 nie mniej niż 80\% przedmiotów w języku łotewskim i wreszcie w szkołach średnich (klasy 10-12) nauczanie wyłącznie po łotewsku. Nowe zasady mają być wprowadzane stopniowo i sukcesywnie w latach 2019-2022 43 .

Zmiany te planowane były od dawna. Już w listopadzie 2017 r. odbyło się w Ambasadzie RP w Rydze spotkanie Ministra Oświaty i Nauki Republiki Łotewskiej Karlisa Sadurskisa z dyrektorami szkół polskich. Podczas spotkania minister starał się rozwiać obawy przedstawicieli społeczności polskiej co do przyszłości szkolnictwa polskiego. Obie strony wyraziły nadzieję, że zmiany nie zagrażają istnieniu szkół polskich ${ }^{44}$.

$\mathrm{Z}$ tą opinią wypadałoby się częściowo zgodzić, gdyż istotnie, zmiany te nie zagrażają samemu istnieniu szkolnictwa polskiego jako takiego. Jednak zawdzięczać to należy korzystnym uwarunkowaniom prawnym, niezależnie od rzeczywistych intencji strony łotewskiej w stosunku do szkół mniejszości narodowych. Podstawą funkcjonowania i istnienia szkół polskich jest bowiem, jak już wcześniej wspomniano, nie tylko wewnętrzne ustawodawstwo łotewskie, ale również dwustronne traktaty i umowy z RP ratyfikowane przez Łotwę. Ponadto warto podkreślić, że przyjęte w polskich szkołach średnich w Rydze, Dyneburgu i Rzeżycy programy i modele nauczania, zaakceptowane przez władze oświatowe, przewidują możliwość nauki niektórych przedmiotów zarówno w języku urzędowym jak i w jednym $\mathrm{z}$ oficjalnych

42 Izglitizibas likums, Saeima, Latvijas Vestnesis 343/344 (1404/1405) 17.11.1998, https://likumi. lv/ta/en/id/50759-education-law [dostęp: 15 II 2018].

43 Grozījumi Izglìtības likumā, Saeima, OP Numurs: 2018/65.1, https://likumi.lv/ta/id/298097grozijumi-izglitibas-likuma [dostęp: 10 V 2018].

44 Ambasada Rzeczypospolitej Polskiej w Rydze, Polacy na Łotwie, https://ryga.msz.gov.pl/pl /aktualnosci/minister_oswiaty_i_nauki_lotwy_na_spotkaniu_z_dyrektorami_polskich_szkol [dostęp: 15 V 2018]. 
języków UE. Szkoły polskie prowadząc nauczanie niektórych przedmiotów w języku polskim opierają się również na tych przepisach, gdyż język polski ma status języka UE. Szkoły rosyjskie na przykład nie mogą korzystać z takich możliwości, gdyż język rosyjski nie jest oficjalnym językiem UE, a wprowadzane zmiany przede wszystkim są właśnie nakierowane na ograniczenie nauczania $w$ języku rosyjskim i częściową chociażby asymilację ludności rosyjskojęzycznej. Generalnie jednak, w dłuższej perspektywie, jest oczywiste, że wprowadzane zmiany ograniczą nauczanie w języku polskim, co z pewnością przyczynić się może do zmniejszenia zarówno znajomości jak i zainteresowania językiem polskim wśród młodzieży polskiego pochodzenia.

Na poziomie edukacji uniwersyteckiej, w 2005 r. na Wydziale Humanistycznym Uniwersytetu w Dyneburgu został utworzony kierunek filologia polska. Były to studia licencjackie, które w zamierzeniu miały kształcić kadrę do pracy w szkołach polskich. Absolwenci mogli kontynuować naukę na uczelniach w Polsce, z którymi Uniwersytet w Dyneburgu od 2006 r. prowadził wymianę studentów i wykładowców ${ }^{45}$.

Mniejszość polska na Łotwie, wkrótce po odbudowie swoich struktur organizacyjnych, rozpoczęła także budowę od podstaw swoich polskojęzycznych mediów. Już w 1991 r. zaczął ukazywać się „Polak na Łotwie”, czasopismo Związku Polaków na Łotwie. Jest to kwartalnik wydawany w nakładzie 500-1000 egzemplarzy, a jego redaktorem naczelnym jest obecnie Ryszard Stankiewicz. Czasopismo opisuje bieżące wydarzenia z życia środowiska polskiego, relacjonuje wydarzenia polityczne i kulturalne ważne dla polskiej społeczności, spotkania polityków polskich i łotewskich, a także przypomina historię Inflant Polskich i wybitne postacie związane z polskością tych ziem ${ }^{46}$. Poza tym od 1996 r. ukazywał się miesięcznik "Czas Łatgalii”, półrocznik „Echo Rygi”, a także „Dodatek Polski”. W Dyneburgu w nakładzie 1500 egzemplarzy wydawany jest „Promien", bezpłatna gazeta będąca organem miejscowego oddziału ZPŁ ${ }^{47}$.

Mniejszość polska na Łotwie posiada też własne programy telewizyjne i radiowe. W Dyneburgu, od 1999 r. w regionalnej telewizji komercyjnej nadawana jest audycja "Na Falach Daugawy". Zapoznaje ona widzów z życiem społeczności polskiej, relacjonuje organizowane przez nią wydarzenia kultu-

45 Daugavpils Universitate, https://du.lv/studijas/ [dostęp 25 II 2018].

46

Polak na Łotwie, Walne zebranie Federacji Mediów Polskich Na Wschodzie, 27.09.2017, https:// polaknalotwie.lv/wydzarzenia/wiadomosci/walne-zebranie-federacji-mediow-polskich-na -wschodzie.html [dostęp: 20 II 2018].

47 Stowarzyszenie Wspólnota Polska, Organizacje polonijne, http://wspolnotapolska.org.pl/ polonia/informacje.php?id=4556/ [dostęp: 12 II 2018]. 
ralne, oświatowe, religijne, rocznice historyczne, opisuje miejscowe tradycje, przedstawia ważne wydarzenia w Polsce i na Łotwie. Jej twórcą i redaktorem naczelnym jest Albina Czibele. W zespole redakcyjnym obecni są uczniowie i absolwenci Gimnazjum Polskiego im. Józefa Piłsudskiego w Dyneburgu. W ten sposób zdobywają oni umiejętności i kompetencje w mediach audiowizualnych. W pierwszych latach funkcjonowania redakcja nie miała żadnego wsparcia finansowego z Polski. Dopiero od 2003 r. przyszła z pomocą Fundacja „Pomoc Polakom na Wschodzie”, która dofinansowuje koszty emisji. Ta sama redakcja przygotowuje też audycję radiową "Głos Młodych Polaków", nadawaną w tamtejszej popularnej rozgłośni "Alise plus" 48.

Od 2005 r. w telewizji kablowej emitowany jest program „Akcenty Polskie". Patronuje mu dyneburski oddział Związku Polaków na Łotwie, a program koncentruje swoją uwagę na działalności Domu Polskiego i Centrum Kultury Polskiej w Dyneburgu, prezentując ich działalność i relacjonując wydarzenia związane $\mathrm{z}$ ich aktywnością. $\mathrm{Z}$ uwagi na mnogość wydarzeń kulturalnych, festiwali, koncertów, wystaw, wernisaży, "Akcenty Polskie" raz $\mathrm{w}$ tygodniu emitują program będący filmową relacją $\mathrm{z}$ tych wydarzeń. Są tam również spotkania i wywiady z uczestnikami i gośćmi festiwali z kraju i zagranicy. Stałe miejsce zajmują relacje $\mathrm{z}$ obchodów rocznic historycznych związanych z Polską, jak i regionem Łatgalii. Ważnym punktem programu są też programy historyczno-geograficzne, w których pokazywane są ciekawe miejsca dawnych Inflant, gdzie zachowały się ślady polskości, prezentowana jest historia tych miejsc, ludzi z nimi związanych, a także pokazywani są miejscowi Polacy zasłużeni dla regionu. Program nadawany jest w każdą sobotę o godz. 20.40. Archiwalne nagrania dostępne są w Internecie, również na Facebooku ${ }^{49}$.

Od 2008 r. nadawany jest też radiowy, religijny program duszpasterski będący rezultatem współpracy z zakonem Ojców Marianów. Z programów radiowych warto też wspomnieć o nadawanej od 2008 r. w regionalnej dyneburskiej stacji radiowej „Alise plus”, audycji „Polskofalówka”. Jej twórcami byli absolwenci filologii polskiej na Uniwersytecie w Dyneburgu, którzy wcześniej przeszli trzymiesięczne szkolenia w Polskim Radiu. Cieszy się ona dosyć dużym zainteresowaniem, a profil programowy obejmuje wiadomości, poradniki językowe, kulinarne, przewodniki geograficzne po Polsce,

48 A. Czibele, Na Falach Daugawy, „Polak na Łotwie” 2008, nr 4 (86).

49 Polak Na Łotwie, TV Akcenty Polskie, https://polaknalotwie.lv/media/akcenty-polskie/ [dostęp 20 II 2018]; Facebook.com/ckp.dagavpils, https://www.facebook.com/ckp.daugav pils/?fref=pb\&hc_location=profile_browser [dostęp: 20 II 2018]. 
a przede wszystkim programy muzyczne, gdzie prezentowani są wyłącznie polscy artyści i polska muzyka ${ }^{50}$. Z kolei w IV programie Radia Łotewskiego nadawana jest raz w miesiącu polska audycja "Nasz Głos”, tworzona w Rydze przez Irenę Liegeenie ${ }^{51}$.

Część opisywanych tu polskich mediów jest dostępna w Internecie, gdzie można obejrzeć archiwalne programy, a także są one obecne w mediach społecznościowych, w tym również na Facebooku. Spełniają one niezwykle ważną rolę w podtrzymywaniu kultury i języka polskiego na Łotwie.

Działalność wszystkich instytucji i organizacji mniejszości polskiej na Łotwie jest wspierana ze środków finansowych pochodzących z Polski. Głównymi instytucjami zajmującymi się udzielaniem takiej pomocy są Senat RP, Ministerstwo Spraw Zagranicznych RP, Ambasada RP w Rydze oraz fundacja „Pomoc Polakom na Wschodzie”. Pomoc świadczy również bardzo wiele mniejszych fundacji, również prywatnych.

Przeprowadzane badania i analiza obecnej sytuacji mniejszości polskiej na Łotwie prowadzi do szeregu wniosków. Zmiany polityczne i odzyskanie niepodległości przez Łotwę w 1991 r. otworzyły nowy, współczesny okres obecności polskiej w tym kraju. Polacy mieli swój skromny, ale ważny udział w walce Łotyszy o niepodległość. Dzięki temu władze nowego państwa łotewskiego od początku odnosiły się z sympatią i zrozumieniem do działań organizacyjnych społeczności polskiej. Polacy, korzystając z praw i możliwości, jakie stworzyło nowe demokratyczne państwo, od początku przystąpili do odbudowy struktur organizacyjnych, szkolnictwa polskiego i działalności społecznej i kulturalnej. Wzorem były instytucje i organizacje działające w dwudziestoleciu międzywojennym. Trzeba podkreślić, że tworzenie organizacji, struktur i szerokie spektrum działań organizacyjnych odbyło się własnymi siłami społeczności polskiej, z niewielką tylko pomocą państwa polskiego.

Na Łotwie Polacy postrzegani są bardzo pozytywnie, wręcz jako wzorcowy przykład funkcjonowania mniejszości narodowej. Władze łotewskie podkreślają, że mniejszość polska działa zgodnie z prawem, integruje się ze społeczeństwem łotewskim i jest lojalna w stosunku do państwa łotewskiego. Zupełnie odwrotnie i negatywnie oceniana jest mniejszość rosyjska.

Mimo wielu pozytywnych działań i osiągnięć organizacyjnych, społeczności polskiej na Łotwie nie udało się jednak jak dotąd stworzyć stabilnych

50 Polskofalówka.com, O nas, http://polskofalowka.com/pl/O-NAS, [dostęp: 20 II 2018].

51 D. Rubene, Rola polskojęzycznych mediów lokalnych w krzewieniu kultury polskiej w Łatgalii (na Łotwie), „Acta Universitatis Lodziensis. Folia Litteraria Polonica” 2015, nr 3(29), s. 99-105. 
warunków do dalszego pomyślnego rozwoju. W porównaniu z osiągnięciami i dorobkiem organizacyjnym wypracowanym $\mathrm{w}$ okresie międzywojennym, liczba instytucji, organizacji społecznych i kulturalnych, tytułów prasowych, oraz przede wszystkim szkół polskich jest obecnie znacząco mniejsza. Problemem jest zwłaszcza stosunkowo niewielkie zaangażowanie i aktywność młodego pokolenia Polaków na Łotwie.

Wielkim problemem jest słaba znajomość języka polskiego i co gorsza, nie jest on używany w kontaktach codziennych. W wyniku długotrwałej rusyfikacji i sowietyzacji ogółu ludności w okresie ZSRR, część Polaków utraciła tożsamość narodową, a większość znajomość ojczystego języka. Mimo odbudowy szkolnictwa polskiego, nie widać istotnego postępu w tej kwestii. Nie sprzyja temu rosyjskojęzyczne w większości otoczenie i mieszane małżeństwa i rodziny, w których dominuje język i kultura rosyjska.

W dłuższej perspektywie pod znakiem zapytania stoi przyszłość szkolnictwa polskiego na Łotwie. Duża część dzieci i młodzieży pochodzenia polskiego nie uczęszcza do szkół polskich, wybierając rosyjskie. Przyczyną jest prawdopodobnie, właśnie brak znajomości języka polskiego. Tworzy się $\mathrm{w}$ ten sposób sytuacja patowa. $Z$ drugiej strony, do niepewności co do przyszłości szkół polskich przyczynia się długofalowa polityka państwa łotewskiego preferująca nauczanie $w$ języku urzędowym. Ma to związek z problemami państwa łotewskiego z mniejszością rosyjską i w konsekwencji chęcią neutralizacji mniejszości narodowych poprzez asymilację.

Społeczność polska na Łotwie odczuwa też brak wykształconych elit, które uczestniczyłyby w życiu społecznym i politycznym Łotwy, tym samym tworząc swój pozytywny wizerunek i jednocześnie mając wpływ na politykę państwa. Część Polaków starszego pokolenia, z powodu braku znajomości języka łotewskiego nie posiada nawet obywatelstwa, pozbawiona jest więc w konsekwencji możliwości pełnienia szeregu ról społecznych.

Mniejszości polskiej na Łotwie jest udzielana pomoc finansowa i organizacyjna przez szereg instytucji polskich. Jednak przez dłuższy okres, zwłaszcza zaraz po wojnie, pomoc ta była bardzo skromna. Przez wiele lat władze polskie wykazywały małe zainteresowanie Polakami na Łotwie. Można powiedzieć, że tamtejsza społeczność polska była jakby zapomniana i pozostawiona sama sobie. Obecnie zainteresowanie i pomoc są znacznie większe. Jednak wydaje się, że nadal są niewystarczające, a bez zwiększenia wsparcia mniejszość polska na Łotwie może nie przetrwać. Wydaje się, że dla zachowania obecności społeczności polskiej i kultury polskiej na Łotwie takie wsparcie musi być kontynuowane i zwiększane. 


\section{Bibliografia}

\section{Źródła}

Education Law, Latvijas Vestnesis, 343/344 (1404/1405), 17.11.1998., "Ziņotājs", 24, 24.12.1998.

Grozījumi Izglītības likumā, Latvijas Vestnesis, 65 (6151), 02.04.2018. OP numurs: 2018/65.1

Europejska Karta Języków Regionalnych lub Mniejszościowych, Strasburg 1992.

Results of the Population and Housing Census 2011, CSB (Latvijas Statistika) 2011.

Rozporządzenie Ministra Edukacji Narodowej RP w sprawie zasad wspomagania nauczania historii, geografii i języka polskiego wśród Polonii oraz zakresu świadczeń przystugujacych nauczycielom polskim skierowanym w tym celu do pracy za granica, Dz.U. 1992 r., nr. 63, poz. 316.

Statut Związku Polaków na Łotwie, Ryga 2005.

Umowa między Rzadem Rzeczypospolitej Polskiej a Rządem Republiki Łotewskiej o wspótpracy kulturalnej, naukowej i oświatowej, sporządzona w Rydze dnia 1 lipca 1992, (Dz.U. 1993 r. nr. 114, poz. 504).

\section{Literatura przedmiotu}

Czibele A., Na Falach Daugawy, „Polak na Łotwie” 2008, nr 4 (86).

Eberhardt P., Przemiany narodowościowe w państwach bałtyckich na przełomie XX $i$ XXI wieku, „Rocznik Nauk Społecznych" 2009, t. 1(37).

Jekabsons E., Polska mniejszość narodowa na Łotwie. Krótka charakterystyka i zarys dziatalności, „Wiadomości Historyczne” 2013, nr 4.

Jekabsons E., Ziemie Łotwy między Wschodem a Zachodem Europy, Lublin 2007.

Kowalski M., Ludność polska w wieloetnicznych regionach Łotwy, Litwy i Białorusi, „Studia z Geografii Politycznej i Historycznej" 2013, nr 2.

Lebedek R., 20 lat bez Ity Kozakiewicz, „Polak na Łotwie” 2010, nr 3 (93).

Leśniewska-Napierała K., Geograficzno-polityczne uwarunkowania sytuacji mniejszości polskiej na Litwie i Łotwie po 1990 roku, Łódź 2015.

Mokrzecka E., Dyrektorka polskiego gimnazjum w Dyneburgu: Polak $i$ Łotysz to bracia, „Znad Wilii", (online), 23.06.2015.

Rubene D., Rola polskojęzycznych mediów lokalnych w krzewieniu kultury polskiej w Łatgalii (na Łotwie), „Acta Universitatis Lodziensis. Folia Litteraria Polonica” 2015, nr 3(29).

Runiewicz-Jasińska R., Oświata polska w niepodległej Litwie, Łotwie i Estonii w latach 1991-2001, Wilno 2003.

Składowski K., Sytuacja ludności polskiej na Ukrainie i Łotwie, [w:] Sytuacja ludności polskiej na Wschodzie w świetle obowiąującego prawa i praktyki, red. D. Górecki, Torun 2009.

Polacy nad Dżwina, red. J. Kurczewski, J. Fuszara, Warszawa 2009. 


\title{
Strony internetowe
}

http://www.csb.gov.lv

http://www.ckp.lv

http://www.du.lv

http://www.eurydice.org.pl

https://www.facebook.com/ckp.daugavpils

http://www.grani.lv/daugavpils

https://www.likumi.lv

http://www.mfa.gov.lv

https://www.msz.gov.pl

https://www.polaknalotwie.lv

http://www.polonia.lv

http://www.polska-szkola.pl

http://www.polskofalowka.com

http://www.gwiazdka.lv

http://www.wspolnotapolska.org.pl

http://www.ryga.msz.gov.pl

http://www.semperpolonia.pl

https://www.vestnesis.lv

http://www.viaa.gov.lv

http://www.zw.lt

\section{Poles in the contemporary Republic of Latvia. Social and cultural activities of the Polish minority}

\begin{abstract}
Summary
Poles are one of the indigenous national minorities of Latvia. Polish presence in this land dates back to the $16^{\text {th }}$ century, that is the times of king Sigismund Augustus' reign. This article presents the demographic, political and social situation of Poles in the contemporary Republic of Latvia. Based on the results of the Latvian census of 2011 the demographic perspective of the Polish minority has been discussed. After the year 1991 as a result of a favourable attitude of the Latvian authorities the Polish community regained the possibility of organisational activity. This study shows the process of reconstructing organizational structures of the Polish community. Also, the process of creating the Polish education system from the ground up has been shown as well as the contemporary challenges faced by Polish schools connected with their internal problems and long-term policy of the Latvian authorities. This work also presents the major problems of the
\end{abstract}


Poles in Latvia and outlines possible perspectives for solving them with the help of Polish authorities and organisations.

The article is just an attempt to outline broader issues which have not yet attracted a larger number of scholars and would require complex and in-depth study.

Wiesław Rymajdo - magister prawa, absolwent UW, absolwent Szkoły Filmowej w Łodzi, absolwent Studiów Wschodnich UwB, doktorant WHS UwB.

e-mail: wrymajdo@interia.pl 